\title{
ANALISIS TINGKAT STRES \\ PADA PASIEN HEMODIALISA DI RSUD ARIFIN ACHMAD PROVINSI RIAU DI MASA PANDEMI COVID-19
}

\author{
Tengku Syahrizal ${ }^{1)}$, Dendy Kharisna ${ }^{2)}$, Veny Dayu Putri ${ }^{3)}$ \\ 1,2,3 Program Studi S1 Keperawatan, STIKes Payung Negeri Pekanbaru \\ Email: dendykharisna@gmail.com
}

Diterima: Desember 2020, Diterbitkan: Desember 2020

\begin{abstract}
ABSTRAK
Progresifitas penyakit gagal ginjal berdampak pada memburuknya kondisi pasien dengan munculnya berbagai komplikasi. Akibatnya pasien harus diberikan berbagai terapi pengobatan, salah satunya hemodialisa demi mempertahankan hidupnya. Hemodialisa (HD) selain membantu mengatasi keluhan pasien, juga dapat memberikan efek negatif bagi fisik maupun psikologis pasien. Selain itu, merebaknya kasus covid-19 dapat mempengaruhi pasien yang harus tetap melakukan HD sesuai jadwal. Tujuan dari penelitian ini adalah untuk menganalisis tingkat stres pada pasien yang menjalani hemodialisa di RSUD Arifin Achmad Propinsi Riau selama pandemi covid-19. Penelitian ini menggunakan pendekatan deskriptif kuantitatif dengan desain cross-sectional. Sampel penelitian berjumlah 47 pasien yang menjalani HD diambil secara accidental sampling. Instrumen yang digunakan adalah kuesioner Depression Anxiety Stres Scale 42 (DASS) dengan berfokus pada dimensi stres. Analisis univariat yang digunakan dalam penelitian ini adalah distribusi frekuensi. Hasil penelitian didapatkan sebagian besar responden laki-laki sebanyak 29 orang $(61,7 \%)$, berusia $>45$ tahun sebanyak 33 orang (70,2\%), dan menjalani HD $>6$ bulan sebanyak 29 orang $(61,7 \%)$. Responden paling banyak melakukan HD 2 kali dalam seminggu sejumlah 27 orang $(57,4 \%)$ dengan durasi HD $>4$ jam sebanyak 25 orang $(53,2 \%)$. Hasil analisis juga menunjukkan sebagian besar responden mengalami stres sangat berat sebanyak 27 orang (57,5\%). Berdasarkan hasil ini, direkomendasikan kepada petugas HD untuk dapat mengedukasi pasien dan memberdayakan peer group guna untuk mengontrol atau mengurangi tingkat stres pasien.
\end{abstract}

Kata Kunci: hemodialisa, pasien, tingkat stress

\section{ABSTRACT}

The progression of kidney failure impacts on the deterioration of the patient's condition with the advent of various complications. As a result, patients have to be given various treatment therapies such as hemodialysis in order to survive. Hemodialysis (HD) aims to treat patient, however it also has negative effects on the patient's physical and psychological condition. In addition, the spread of covid-19 cases affects patients who have to keep doing HD on schedule. The purpose of this study was to analyze the stress level of patients undergoing hemodialysis at the Arifin Achmad Regional Hospital, Riau Province during the Covid-19 pandemic. This study used a quantitative descriptive approach with a cross-sectional design. The study sample consisted of 47 patients who underwent HD taken by accidental sampling. The instrument used was the Depression Anxiety Stress Scale 42 (DASS) questionnaire with a focus on the dimensions of stress. The univariate analysis used in this study is the frequency distribution. The results showed that most male respondents were 29 people (61.7\%), aged $>45$ years were 33 people (70.2\%), and had HD> 6 months as many as 29 people (61.7\%). Most respondents do HD twice a week with 27 people (57.4\%) with a duration of HD> 4 hours as many as 25 people (53.2\%). The results of the 
analysis also showed that most of the respondents experienced severe stress as many as 27 people (57.5\%). Based on these results, it is recommended that HD officers be able to educate patients and empower peer groups to control or reduce patient stress levels.

Keywords: Hemodialysis, patient, stress level

\section{PENDAHULUAN}

Meningkatnya angka kejadian penyakit kronis menjadi permasalahan global disetiap negara, bukan hanya terjadi di negara berkembang tetapi juga menjadi bagi di negara-negara maju. Salah satu penyakit kronis yang menjadi permasalahan yaitu penyakit ginjal kronik. Penyakit ginjal kronik berada diperingkat 10 penyebab kematian di indonesia dengan prevalensi angka kejadiannya pada tahun 2016 sebesar 2\% (499.800 orang) (Kemenkes RI, 2018).

Gagal ginjal kronik menyebabkan kerusakan pada fungsi ginjal yang bersifat progresif dan irreversibel, sehingga membuat tubuh tidak mampu untuk mempertahankan metabolism serta keseimbangan cairan dan elektrolit dalam tubuh yang menyebabkan kondisi uremia (Smeltzer \& Bare, 2010). Oleh karena itu, diperlukan terapi untuk menggantikan peran ginjal dalam tubuh yang dikenal dengan hemodialisa (Suparti, 2017). Secara global ada sekitar 2 juta penduduk dunia melakukan terapi hemodialisa (HD) dari $10 \%$ penduduk dunia yang mengalami penyakit gagal ginjal. Penduduk Indonesia yang tercatat melakukan terapi hemodialisa di tahun 2016 ada 25.446 pasien baru dan 52.835 pasien lama (Kemenkes RI, 2018).

Septiwi (2011) mengatakan hemodialisa dapat dilakukan 2-3 kali perminggu dengan durasi waktu yang berbeda tergantung dari jenis frekuensi HD yang dipilih oleh pasien. Hemodialisa selain bermanfaat dan berperan dalam menjalankan fungi ginjal hemodialisa juga memiliki dampak yang buruk bagi pasien berupa komplikasi akut dan komplikasi kronis. Komplikasi akut yang terjadi yaitu hipotensi, hipertensi, reaksi alergi aritmia, emboli udara, kram otot, mual, muntah, sakit kepala, sakit dada, sakit punggung, gatal, demam, dan menggigil. Sedangkan komplikasi kronis yang dapat terjadi antara lain penyakit jantung, malnutrisi, hipertensi, anemia, renal osteodystrophy, neuropathy, disfungsi reproduksi, gangguan perdarahan, infeksi, amiloidosis, acquired cystic kidney disease (Himmerfarb \& Ikizler, 2010).

Bulut (2017) menambahkan beberapa kerugian lain yang dialami oleh pasien dengan hemodialisa diantaranya kelemahan fisik, penurunan kemampuan kognitif, dan penurunan peran dalam keluarga. Selain itu, HD juga dapat memicu respon stres pada pasien yang menjalaninya (Suwira, 2014; Tu et al., 2014). Stresor psikologis yang dialami oleh pasien yang menjalani HD diakibatkan oleh beberapa hal diantaranya pembatasan cairan, pembatasan diet, gangguan tidur, ketidakjelasan tentang masa depan, pembatasan aktivitas rekreasi, penurunan kehidupan sosial, pembatasan waktu dan tempat bekerja, lamanya proses dialisis serta faktor ekonomi.

Stres merupakan kumpulan perubahan fisiologis sebagai respon tubuh terhadap tuntutan kehidupan akibat adanya ancaman atau bahaya ataupun pencetus lain yang disebut stresor yang dipengaruhi oleh lingkungan seseorang berada (Sunaryo, 2013). Perry dan Potter (2010), juga mengungkapkan seseorang yang mengalami stres terjadi karena adanya kebutuhan dari individu tidak terpenuhi dan kebutuhan tersebut 
dapat berupa kebutuhan fisiologis, psikologis, sosial, tumbuh kembang, lingkungan, spiritual, maupun kultural. Adanya kebutuhan yang tidak terpenuhi tersebut dapat menjadi stimulus yang memicu terjadi stres pada individu tersebut.

Rahayu, Ramlis, dan Fernando (2015), mengatakan bahwa pasien yang mengalami stres berat terjadi akibat rasa cemas karena kondisi penyakitnya, komplikasi yang terjadi, dan kondisi ekonomi selama sakit. Selain itu, kondisi penyakit yang diderita serta ketergantungan secara terus menerus terhadap pengobatan yang dijalani akan memberikan tekanan dan pengaruh negatif berupa stresor bagi pasien (Baykan \& Yargic, 2012). Stres yang tidak tertangani cenderung berlanjut pada kondisi depresi yang justru memperburuk kondisi kesehatan pasien. Kondisi ini diperparah dengan kasus covid-19 yang saat ini sedang mewabah di seluruh dunia, Pekanbaru dan Propinsi Riau pun tidak luput dari pandemi covid-19. Terlebih lagi saat ini Pekanbaru berasa dalam zona merah dan masih minimnya literasi terkait covid-19.

Berdasarkan fenomena tersebut menjadi penting untuk melakukan pendekatan pada stres yang dialami oleh pasien yang menjalani HD dengan mengkaji tingkat stres yang dialami pasien HD. Hal ini menjadi penting untuk dilakukan karena berpotensi dalam upaya pencegahan stres yang dapat dialami oleh pasien terlebih di masa pandemi covid-19 yang terjadi saat ini. Oleh karena itu, peneliti tertarik untuk meneliti tentang "Analisis tingkat stres pada pasien yang menjalani hemodialisa di RSUD Arifin Achmad Propinsi Riau di Masa Pandemi Covid-19”.

\section{METODE PENELITIAN}

Penelitian ini menggunakan pendekatan deskriptif kuantitatif dengan rancangan cross-sectional. Jumlah sampel yang digunakan dalam penelitian adalah 47 orang yang tercatat sebagai sebagai pasien di ruangan HD RSUD Arifin Achmad Propinsi Riau dan saat ini sedang menjalani program HD. Teknik samping yang digunakan adalah accidental sampling. Selama proses pengumpulan data peneliti dibantu oleh petugas HD yang membantu menjelaskan tujuan dan maksud penelitian secara langsung kepada pasien dikarenakan peneliti tidak diperbolehkan bertemu secara langsung dengan responden dikarenakan adanya physical dan social distancing selama penerapan kebijakan Pembatasan Sosial Berskala Besar (PSBB) di Pekanbaru.

Petugas di ruangan HD juga membantu mengumpulkan nomor handphone whatsapp pasien dan data alamat pasien serta menyampaikan kepada responden akan dimasukkan ke grup whatsapp untuk penelitian. Selanjutnya peneliti menginvite responden ke dalam grup tersebut. Grup whatsapp ini menjadi sarana bagi peneliti dalam menjelaskan kembali tujuan dan maksud penelitian serta prosedur penelitian.

Instrumen penelitian berupa kuesioner yang terdiri atas dua bagian. Bagian pertama berisikan data demografi responden, sedangkan bagian kedua khusus memuat tentang penilaian tingkat stres responden. Kuesioner yang digunakan adalah Depression Anxiety Stress Scale 42 (DASS 42) yang dikembangkan oleh Lovibond dan Lovibond tahun 1995. Instrument ini dibuat dalam bentuk google form yang kemudian linknya dibagikan ke responden. Kuesioner ini terdiri atas 14 item pernyataan yang menilai aspek stress responden berdasarkan indikator gejala fisik, psikologis, dan perilaku (Sari, 2019). Analisis univariat yang digunakan adalah distribusi frekuensi berdasarkan jenis kelamin, usia, lama menjalani HD, durasi dan frekuensi HD 
serta tingkat stres yang dialami oleh responden.

\section{HASIL DAN PEMBAHASAN}

Tabel 1. Distribusi Frekuensi Responden

Berdasarkan Jenis Kelamin, Usia, Lama,

Frekuensi, dan Durasi Melakukan HD di RSUD Arifin Achmad Provinsi Riau ( $\mathrm{n}=47)$

\begin{tabular}{|c|c|c|c|}
\hline No & Variabel & Frekuensi & Persentase (\%) \\
\hline \multirow[t]{4}{*}{1} & Jenis kelamin & & \\
\hline & Laki-laki & 29 & 61,7 \\
\hline & Perempuan & 18 & 38,3 \\
\hline & & 47 & 100 \\
\hline \multirow[t]{5}{*}{2} & Usia & & \\
\hline & 25-34 tahun & 1 & 2,1 \\
\hline & 35-44 tahun & 13 & 27,7 \\
\hline & $>45$ tahun & 33 & 70,2 \\
\hline & & 47 & 100 \\
\hline \multirow[t]{4}{*}{3} & Lama melakukan & & \\
\hline & $\mathrm{HD}$ & 18 & 38,3 \\
\hline & $\begin{array}{l}\leq 6 \text { bulan } \\
>6 \text { bulan }\end{array}$ & 29 & 61,7 \\
\hline & & 47 & 100 \\
\hline \multirow[t]{5}{*}{4} & Frekuensi & & \\
\hline & melakukan HD & 10 & 213 \\
\hline & 1 kali seminggu & 27 & 57,4 \\
\hline & 2 kali seminggu & 10 & 21,3 \\
\hline & & 47 & 100 \\
\hline \multirow[t]{6}{*}{5} & Durasi melakukan & & \\
\hline & $\mathrm{HD}$ & & \\
\hline & 1-2 jam & $\begin{array}{c}0 \\
16\end{array}$ & $\begin{array}{l}12,8 \\
340\end{array}$ \\
\hline & 3-4 jam & $\begin{array}{l}16 \\
25\end{array}$ & $\begin{array}{l}34,0 \\
532\end{array}$ \\
\hline & $>4$ jam & & \\
\hline & & 47 & 100 \\
\hline
\end{tabular}

didapatkan sebagian besar responden lakilaki sebanyak 29 orang $(61,7 \%)$, berada di atas 45 tahun sebanyak 33 orang $(70,2 \%)$, lama melakukan HD $>6$ bulan sebanyak 29 orang $(61,7 \%)$, melakukan HD sebanyak 2 kali seminggu sebanyak 27 orang $(57,4 \%)$, dan melakukan 1 kali HD dengan durasi $>4$ jam sebanyak 25 orang $(53,2 \%)$.

Black dan Hawks (2014) mengatakan bahwa pola hidup atau kebiasaan laki-laki seperti merokok, mengkonsumsi alkohol, kopi dan suplemen menjadi faktor resiko timbulnya penyakit gagal ginjal yang berujung pada HD. Kemenkes RI (2018) juga menyatakan bahwa prevalensi laki-laki dan perempuan yang mengalami penyakit gagal ginjal adalah $60 \%$ laki-laki dan $40 \%$ perempuan. Selain itu, Syaiful, Oenzil, dan
Afriant, (2014) dalam penelitiannya mendapatkan bahwa jumlah laki-laki (36 orang) yang menjalani HD lebih banyak daripada perempuan (23 orang).

Pada karakteristik usia, dapat dilihat bahwa sebagian besar responden berumur lebih dari 45 tahun. Ketika individu berada pada usia 40-70 tahun, laju filtrasi glomerulus (LFG) mengalami penurunan secara progresif hingga $50 \%$ dari fungsi awalnya, sehingga dapat menyebabkan terjadinya penurunan kemampuan tubulus, mulai dari pemekatan urin, reabsorbsi, pengosongan kandung kemih yang juga bisa beresiko menyebabkan infeksi dan obstruksi (Septiwi, 2010). Hal ini sesuai dengan penelitian yang dilakukan Bertalina dan Sumardilah (2012), tentang faktor-faktor kepatuhan diet pasien gagal ginjal kronik yang menjalani hemodialisa. Hasil penelitiannya menunjukkan jumlah responden terbanyak berada pada rentang usia 41-60 tahun.

Hasil penelitian menunjukkan responden paling banyak sudah melakukan HD $>6$ bulan dengan frekuensi 2 kali seminggu selama $>4$ jam untuk tiap kali HD. Frekuensi dan durasi hemodialisa bervariasi dan dapat dipilih sesuai dengan kondisi pasien. HD dapat dilakukan 2-3 kali seminggu selama 10-12 jam perminggu atau setidaknya untuk satu kali melakukan HD berlangsung selama 4-5 jam (Septiwi, 2011). Hasil penelitian ini sejalan dengan penelitian yang dilakukan oleh Befly dkk (2015), menunjukan bahwa responden yang menjalani hemodialisis $\leq$ 6 bulan sebanyak 15 orang $(44,1 \%)$ dan $>$ 6 bulan sebanyak 19 orang $(55,9 \%)$.

Ibrahim (2012) menyatakan frekuensi terapi hemodialisa pada setiap orang tergantung dari tingkat kerusakan fungsi ginjal pasien, terapi hemodialisa idealnya dilakukan sampai 3 kali perminggu dengan durasi waktu 4-5 jam sekali melakukan terapi hemodialisa. Akan tetapi ada juga yang melakukan HD hanya satu kali dalam seminggu. Banyaknya pertimbangan seperti masalah finansial dan 
akses yang tidak mudah dijangkau menjadi alasan bagi sejumlah pasien.

Pasien dengan resiudal kidney function rendah (kurang dari $2 \mathrm{ml} /$ menit) harus menjalani hemodialisa 3 kali seminggu dengan durasi 3 setiap kali melakukan hemodialisa (Daugirdas et al, 2015). KDOQI (Kidney Dialysis Outtcome Initiative) menyepakati dosis untuk pasien hemodialisa untuk mendapatkan adekuasi yaitu 10-15 jam/minggu. Pelaksanaan hemodialisa dengan durasi 4-5 jam dilakukan 3 kali seminggu, dan durasi untuk 5-6 jam dilakukan dengan 2 kali seminggu.

Tabel 2. Distribusi Frekuensi Responden Berdasarkan Tingkat Stres di RSUD Arifin

\begin{tabular}{cccc}
\multicolumn{4}{c}{ Achmad Provinsi Riau $(\mathrm{n}=47)$} \\
\hline No & Tingkat & Frekuensi & $\begin{array}{c}\text { Persentase } \\
\mathbf{( \% )}\end{array}$ \\
\hline 1 & Stres & & 10,6 \\
2 & Stres ringan & 5 & 21,3 \\
3 & Stres sedang & 10 & 10,6 \\
4 & Stres berat & 5 & 57,5 \\
& Stres sangat & 27 & \\
\hline & berat & & 100.0 \\
\hline
\end{tabular}

Berdasarkan tabel diatas dapat dilihat bahwa tingkat stress paling banyak yang dialami responden selama menjalani HD adalah stress sangat berat sebanyak 27 orang $(57,5 \%)$. Responden paling sedikit berada tingkat stres ringan dan berat masing-masing sebanyak 5 orang $(10,6 \%)$. Hasil penelitian ini menunjukkan sebagian besar responden yang mengalami stres berat adalah pasien yang menjalani lama hemodialisa kurang dari 6 bulan yaitu sebanyak 14 orang (51,9\%). Rahayu, Fernandos, dan Ramlis (2018) mengungkapkan bahwa pasien yang baru menjalani proses hemodialisa akan mudah mengalami stres akibat adanya perubahan gaya hidup yang dialaminya. Semakin lama pasien menjalani proses hemodialisa akan semakin adaptif mekanisme koping dari pasien tersebut. Pasien yang sudah lama menderita CKD memiliki banyak pengalaman dalam berbagai macam bentuk stressor, sehingga pasien dapat mudah beradaptasi dengan dengan kondisinya tersebut.
Hasil penelitian ini juga
didapatkan sebagian besar yang mengalami stres berat adalah frekuensi hemodialisa 3 kali seminggu yaitu sebanyak 10 pasien (100\%), dengan durasi untuk satu kali hemodialisa $>4$ jam yaitu sebanyak 9 orang. Proses hemodialisa yang berlangsung lama bagi pasien baru menjalani HD tentu akan sangat terasa panjang dan melelahkan. Hal ini akan membuat pasien merasa jenuh, bosan, dan bahkan ada juga yang tidak menerima perubahan kondisi dan rutinitas hariannya dikarenakan harus menyelesaikan program terapi HD nya secara teratur. Ketergantungan terhadap terapi hemodialisa dan ketidaksiapan terhadap adanya perubahan gaya hidup ini menjadi pencetus stres bagi pasien (Colvy, 2010). Lamanya waktu yang dihabiskan untuk tiap satu kali HD yang rutin dilakukan setiap minggunya membuat setiap minggunya dapat mengganggu fungsi dan peran pasien yang berujung menjadi stressor.

Corwin (2015) menambahkan hemodialisa menyita waktu dan tenaga bagi pasien yang menjalani HD. Berbagai perubahan dalam kehidupan yang terjadi pada pasien hemodialisa karena menyebabkan adanya ketidak seimbangan antara tuntutan dan sumber daya yang dimiliki individu. Semakin tinggi jarak kesenjangan yang terjadi maka makin tinggi pula tingkat stres yang dialami individu (Ibrahim, 2012). Selain itu Rahayu, Fernandoz, dan Ramlis (2018) dalam penelitiannya menambahkan bahwa pasien yang menjalani terapi hemodialisa mengalami stres berat akibat mencemaskan kondisi penyakitnya, komplikasi yang terjadi, dan kondisi ekonomi selama sakit. Sari, Elita, dan Novayelinda (2014) dalam penelitiannya menyatakan bahwa tingkat stress yang dialami pasien hemodialisa berhubungan dengan kemampuan mekanisme ataupun strategi kopingnya. Peneliti berasumsi selain diakibatkan faktor-faktor diatas, tingginya stress yang dialami pasien juga 
berasal dari mekanisme koping yang kurang adaptif terhadap kondisi penyakitnya ditambah lagi dengan situasi pandemi covid-19 yang saat ini sedang terjadi.

\section{SIMPULAN}

dapat $\begin{array}{rrr}\text { Berdasarkan hasil penelitian } \\ \text { disimpulkan }\end{array}$ responden yang sedang menjalani terapi HD saat ini mengalami stress, mulai dari stress ringan, sedang, berat dan sangat berat dengan berbagai sumber stresor. Responden yang baru menjalani HD memiliki kecenderungan mengalami tingkat stres yang lebih tinggi apalagi dengan durasi HD yang lama lebih dari 4 jam dan dengan mekanisme koping serta kemampuan adaptasi yang buruk.

\section{UCAPAN TERIMAKASIH}

Penulis mengucapkan terimakasih kepada seluruh responden yang telah berpartisipasi dalam penelitian ini. Selanjutnya kepada petugas HD yang ikut membantu dan memfasilitasi semua proses pengumpulan data penelitian. Ucapan terimakasih juga penulis berikan kepada STIKes Payung Negeri Pekanbaru yang telah mendukung penelitian ini hingga awal sampai akhir.

\section{DAFTAR PUSTAKA}

Baykan H., \& Yargic I. (2012). Depression, anxiety disorders, quality of life and stress coping strategies in hemodialysis and continuous ambulatory peritoneal dialysis patients. Bulletin of Clinical of Pharmacology, 22 (2)

Bertalina \& Sumardilah. (2012). Faktor kepatuhan diet GGK yang menjalani hemodialis. Diakses pada tanggal 27 Maret 2020 dari htttp://academia.edu.

Black,J dan Hawks, J. (2014). Keperawatan medikal bedah: Manajemen klinis untuk hasil yang diharapkan.
Diterjemahkan oleh Nampira R. Jakarta: Salemba Emban Patria.

Bulut, A. (2017). Depression levels of the hemodialysis patients living in bingol city center. International journal of caring sciences, 10(3), 1248.

Colvy, J. (2010). Tips cerdas mengenali dan mencegah gagal ginjal. Yogyakarta: DAFA Publishing

Corwin, E. J, (2009). Buku saku patofisiologi 3. Jakarta: EGC

Daugirdas, J. T., Depner, T. A., Inrig, J., Mehrotra, R., Rocco, M. V., Suri, R. S., ... \& Olson, C. (2015). Kdoqi clinical practice guideline for hemodialysis adequacy: 2015 update. American journal of kidney diseases, 66 (5), 884-930.

Himmelfarb, J. \& Ikizler, T.A. (2010). Hemodialysis. $N$ Engl JMed. 363(19):1833-45.

Kementrian Kesehatan Republik Indonesia, (2018). Air bagi kesehatan: Upaya peningkatan promotif dan preventif bagi kesehatan ginjal di indonesia. Jakarta. Diakses pada tanggal 20 Maret 2018, dari https//www.kemenkes.go.id

Lovibond, S.H. \& Lovibond, P.F. (1995). DASS 42. Diakses pada tanggal 6 April 2020, dari http://www.psy.unsw.edu.au/dass/art icle/

Perry \& Potter. (2010). Buku ajar fundamental keperawatan: Konsep, proses dan praktik. Edisi 7. Vol.3. Jakarta : EGC

Rahayu, F., Fernandoz, T., \& Ramlis, R. (2018). Hubungan frekuensi hemodialisis dengan tingkat stres pada pasien gagal ginjal kronik yang menjalani hemodialisis. Jurnal keperawatan silampari, 1(2), 139153.

Sari, Y. Elita, V. Novayelinda, R. (2014). Hubungan tingkat stres dan stategi koping pada pasien yang menjalani terapi hemodialisa. Diakses pada tanggal 6 April 2020 dari https://scholar.google.co.id/scholar? $\mathrm{hl}=\mathrm{id} \&$ as_sdt $=0 \% 2 \mathrm{C} 5 \& \mathrm{q}=$ Hubunga 
$\mathrm{n}+$ tingkat + stres + dan + stategi + koping + pada + pasien + yang + menjalani+tera pi + hemodialisa\&btnG $=$ article/

Sari, E. T. (2019). Stres dalam hubungannya dengan fatigue pada pasien yang menjaiani terapi hemodialisa di unit hemodiallisa rs $d r$. Haryoto Lumajang. Di akses pada tanggal 6 april 2020 dari https://repository.unej.ac.id/handle/1 23456789/91069=article/ Septiwi, C. (2013). Pengaruh breathing exercise terhadap level fatigue pasien hemodialisis di rspad gatot subroto jakarta. Jurnal ilmiah kesehatan keperawatan, 9(2).

Smeltzer, S. C., Bare, B. G. (2010). Buku ajar keperawatan medikal bedah. Edisi 12. Jakarta : EGC

Suparti, S., \& Nurjanah, S. (2018). Hubungan depresi dengan fatigue pada pasien hemodialisis. Ejournal unisa yogya, 2(01).

Sunaryo. (2013). Psikologi untuk keperawatan. Jakarta: EGC

Suwitra K.(2014). Penyakit Ginjal Kronik. Dalam: I Setiati S, Alwi I, Sudoyo AW, SImadibrata M, Setyohadi B, penyunting. Buku Ajar Ilmu Penyakit Dalam. Jakarta: Pusat Penerbitan Departemen Ilmu Penyakit Dalam FKUI.

Tu HY, Shao JH, Wu FJ, Chen SH, CY. (2014). Stressors and coping strategies of 20-45-year-old hemodialysis patients. Collegian (Royal College of Nursing, Australia). 21(3):1-8. 